\author{
ACTA MYCOLOGICA \\ Vol. 44 (1): 11-17 \\ 2009
}

\title{
Some endophytes of Juncus trifidus from Tatra Mts. in Poland
}

\author{
ANDRZEJ CHLEBICKI \\ Department of Mycology, W. Szafer Institute of Botany, Polish Academy of Sciences \\ Lubicz 46, PL-31-512 Kraków, a.chlebicki@botany.pl
}

Chlebicki A.: Some endophytes of Juncus trifidus from Tatra Mts. in Poland. Acta Mycol. 44 (1): 11-17, 2009.

This is a first part of work devoted highland rush endophytes: Penicillium expansum, Cladosporium oxysporum, Arthrinium state of Apiospora montagnei and Aureobasidium pullulans. The basidiomycete strain, possibly Lagarobasidium detriticum was also isolated.

Key words: highland rush, basidiomycete endophyte, Arthrinium, Penicillium, Cladosporium, Aureobasidium

\section{INTRODUCTION}

Asymptomal fungal infections within tissues of healthy plants is a basic character of endophytic fungi. These fungi can be dormant saprotrophs, latent pathogen as well as mutualistic symbionts (Stone et al. 2000). Sieber et al. (1991) noted that the latent endophyte phase is inversely related to the virulence of pathogen. Fungal endophytes belong to different taxonomical groups of fungi such as Ascomycetes and their anamorphs, mitosporic fungi and very rare basidiomycetous fungi. There are some tentatively using groups of endophytes as xylariaceous endophytes, DSE (dark septate endophytes), aquatic mitosporic fungi, clavicipitaceous endophytes and others. Of them fungi from the order Clavicipitales are well known and evolutionary advanced endophytes (Bacon, Hill 1996). According to Clay (1989) and White (1987) clavicipitaceous endophytes are widely distributed in the grass family Poaceae and sporadically distributed in Cyperaceae and Juncaceae. Other non-clavicipitaceous endophytes were noted in grasses (see Larran et al. 2002) and rarely in rushes. According to Powell (1975) rushes and sedges are non-mycotrophic, avoid of mycorrhiza. Some endpohytes in rushes leaves of annual J. bufonius, perennial J. effusus, J. patens and J. bolanderi were reported by Cabral et al. (1993). Perennial rushes were inhabited by limited diversity of fungal species, mostly anamorphs and 
teleomorphs of dothidealen fungi, but only one or two species were recorded in high frequency. Whereas annual rush was inhabited by distinctly diverse assemblage of mitosporic fungi including aquatic fungi with low isolation frequencies. According to Cabral et al. (1993) rush endophytes were restricted to single epidermal host cell - Stagonospora innumerosa (Desm.) Sacc., substomatal cavity - Drechslera sp., Cladosporium cladosporoides, Alternaria alternata, and intercellular area of mesophyll tissue - Phaeosphaeria juncicola and Alternaria alternata. Menéndez et al. (1997) noted Platysporoides aff. togwotiensis (Wehm.) Shoemaker \& C. E. Babc. as endophyte in substomatal chamber of Juncus imbricatus var. chamissonis.

There are some articles devoted microfungi inhabiting different rushes. Volkmann-Kohlmeyer and Kohlmeyer (1994) and Kohlmeyer and Volkmann-Kohlmeyer (2000) described some marine fungi from saltmarsh Juncus roemerianus. Adamska (2005) noted six microfungi on various Juncus species in lowland of Poland. 30 taxa of microfungi (Tab. I) were noted on highland rush by Scheuer (1988, 1996, 1999); Chlebicki (1990, 2002); Scheuer \& Chlebicki (1997); Suková (2004) and Suková \& Chlebicki (2004) in the Alps, Carpathians, Sudetes and Ural Mts.

Table 1

List of fungal species noted on plant organs of J. trifidus

\begin{tabular}{|l|l|}
\hline Arthrinium cuspidatum & Lophodermium juncinum \\
\hline Arthrinium state of Apiospora montagnei & Mycosphaerella perexigua \\
\hline Ascochyta junci & Naeviella paradoxa \\
\hline Brikookea sepalorum & Niptera eriophori \\
\hline Botrytis cinerea & Periconia atra \\
\hline Brunnipila calycioides & Phaeosphaeria juncicola \\
\hline Cladosporium herbarum & Phaeosphaeria vagans \\
\hline Coronellaria caricinella & Phialocephala $\mathrm{sp}$. \\
\hline Cistella fugiens & Pseudoseptoria $\mathrm{sp}$. \\
\hline Dinemasporium strigosum & Pycnothyrium junci \\
\hline Diplonaevia emergens & Septoria spp. \\
\hline Epicoccum nigrum & Septoria chanousiana \\
\hline Hysteronaevia minutissima & Stagonospora $\mathrm{sp}$. \\
\hline Hysteropezizella diminuens & Stagonospora junciseda \\
\hline Lachnum dinminutum & Unguicularia $\mathrm{sp}$. \\
\hline Lachnum roseum & \\
\hline
\end{tabular}

Only some endophytes were noted on specimens of Juncus spp.: Pleospora togwotiensis, Stagonospora sp. on Juncus imbricatus - (Menéndez et al. 1997); Stagonospora innumerosa, Alternaria alternata, Phaeosphaeria juncicola, Drechslera sp., Cladosporium cladosporioides, Coniothyrium sp., Exophiala salmonis, Gyoerffyella craginiformis, Spermospora -like sp., Varicosporium elodeae, Helicodendron spp., Gliomastix sp., Lambdosporium, Phoma-like sp., Titaea sp., Acremonium (Neotyphodium) sp., on J. bufonius, J. effuses, J. patens, J. bolanderi - (Cabral et al. 1993). All these species are ascomycete fungi and its anamorphs, or mitosporic fungi.

Host plant. Juncus trifidus L. (highland rush) belongs to the section Steirochloa which is a sister group of Luzula (Drábkova et al. 2003). J. trifidus subsp. trifidus is the amphi-atlantic perennial plants of Boreal-arctic-alpine distribution. The species is divided into three subspecies. Of them J. trifidus subsp. carolinianus occurs in North America, J. trifidus subsp. monanthos is restricted to calcareous area of Alps and Appenines. The typical taxon J. trifidus subsp. trifidus occurs in silicate 
mountains of Europe, Greenland and Northern Asia. The geographical distribution of the plant indicates its European origin (Böcher 1972). Plants from North America resembling those from Greenland and Scandinavia and differ in many characters from strains from Pyrenees and Tatra Mts. (Böcher 1972). During the Pleistocene it spread in the Arctic, reaching central Siberia in the East (Kulczyński 1924). In Poland it occurs in some localities such as the Karkonosze Mts. (the Sudetes), Mt. Babia Góra Range and Tatra Mts. (the Carpathians). The locality in Mt. Śnieżnik in the Central Sudetes, reported by Ciaciura (1988), is situated on the Czech side of this mountain. Highland rush is perennial caespitose rush forming dense tufts. Aerial stems are stiff and erected, leaves alternate, simple with acuminate apices. Inflorescence cymose or head-like. Number of chromosomes of Polish populations $2 \mathrm{n}=30$ (Skalińska et al.1957). It is pioneering alpine species with effective strategy of colonization of disturbed sites (Marchand, Roach 1980).

\section{METHODS}

Material was collected on NE slope of Mt. Małołączniak in the Tatra Mts. $\left(49^{\circ} 55^{\prime} \mathrm{N}\right.$, $\left.19^{\circ} 14^{\prime} \mathrm{E}\right) .19$ specimens of Juncus trifidus were screened for the presence of fungal endophytes. Small part of tuft including culms with rots were removed from the soil into sterile unclosed zip-lock plastic bags and putted in the refrigerator. After 3 days they were moving from the bags and processed according to isolation procedures (Bacon 1990). Three green culms of each sample were selected, central parts of each culm were cut into two segment ca $3 \mathrm{~cm}$ long. Six segments from each sample were used (totally 114 segments). All segments were dipped for $1 \mathrm{~min}$ in $96 \%$ ethanol, then surface sterilized for $3 \mathrm{~min}$ in $3 \%$ chlorox $(\mathrm{NaOCl})$, rinsed in ethanol for $1 \mathrm{~min}$ and transferred to $90 \mathrm{~mm}$ Petri plates with Ferency medium and then were incubated in room temperature in daylight. Obtained isolates of different fungi were then removed on PDA and MAA media and incubated in room temperature. Taxa of fungi were identified on the basis of cultural characteristics and the morphology of hyphae and conidia.

\section{RESULTS}

Totally 114 segments were used. 11 strains of different fungi were isolated. Of them five taxa are presented in this article.

Arthrinium state of Apiospora montagnei Sacc., Nuovo Giorn. Bot. Ital. 7: 306, 1875.

Colonies superficial, widely effused, produced mycelial mats, mycelium colourless to pale olivaceous brown, composed of network of septate hyphae anastomosing and branched, smooth ca $3 \mu \mathrm{m}$ diam, conidiophores colourless, smooth 1.5-2 $\mu \mathrm{m}$ diam., conidia brown 5-9 $\times 4-5 \mu \mathrm{m}$ with a hyaline band at the junction of the two 
sides. The fungus started growth after 5 months from two segments and overgrow every mycelia in the dishes.

COMments. The anamorph of this species was earlier noted by the author on leaves and stems of $J$. trifidus from Ural Mts. The colonies of this Ural collection growing on stems, where circular, black with conidia $4.5-5(6) \times 3.6-5 \mu \mathrm{m}$. It is cosmopolitan species, very common on bamboos and other dead plants (Ellis 1971), with long hosts list (Domsch, Gams and Anderson 1980). The fungi from the genus Arthrinium were isolated from leaves of J. imbricatus var. chamissonis (Menendez et al. 1995), bark of Eucalyptus globulus (Bettucci et al. 1999) and accidentally noted in tomato leaves (Larran et al. 2001) and lichen talli of Cladonia, Stereocaulon (Petrini et al. 1990) and Xanthoparmelia taratica (as Parmelia taratica Girlanda et al. 1997).

Aureobasidium pullulans (De Bary) G. Arnaud, Annals d'École National d'Agric. de Montpellier, N.S. 16: 39, 1918, var. pullulans.

Figs 1A1, A2

Anamorph of Discosphaerina Höhn.

After 10 days at the ends of rush segments appeared two pale colonies (Fig. 1A1) which quickly joined and darken after 30 days (Fig. 1A2). Such black mycelium has been removed to the new plate with PDA. Colony black, convex, slightly pulvinate, surface covered by dense hyphae with conidia, margin entire to undulate, $21 \mathrm{~mm}$ diam. after 7 days. Hyphae hyaline to pale brown, 4-5 $\mu \mathrm{m}$ diam., septate and branched, conidiogenous cells intercalary, conidia very variable in shape, (4)7$10(19) \times(2) 3-4 \mu \mathrm{m}$.

COMMENTs. This black yeast-like fungus (meristematic fungus) is ubiquitous saprophyte of phyllosphere and other aerial plant parts (Domsch, Gams and Anderson 1980). It is frequently noted as endophyte of different plants, among them in bark and xylem of Eucalyptus (Bettucci et al. 1999), leaf fern Pteridium aquilinum (Fisher 1996), twigs, leaves and buds of Acer pseudoplatanus and other trees (Pugh, Buckley 1971). A. pullulans can be antagonistic against a number of phytopathogenic fungi (Andrews et al. 1983). Schena et al. (2002) noted high protection levels of $A$. pullulans against Penicillium digitatum, Botrytis cinerea and Monilia laxa. A. pullulans is also noted on painted wood, stone and glass (Yurlova et al. 1999).

Cladosporium herbarum (Pers.) Link, Ges. Naturf. Freunde Berlin Mag. Neuesten Entdeck. Gesammten Naturk. 7: 37, 1816.

Anamorph of Davidiella tassiana (De Not.) Crous \& U. Braun, Mycol. Progr. 2: 8, 2003.

Conidiophores straith to flexuose, distinctly nodose (were present on three stem segments in a single plate), conidia cylindrical, limoniform, pale olivaceous, nearly smooth or very slightly verrucose 19-16 × 5-6 (7) $\mu \mathrm{m}$.

Comments. Conidia of the species complex of $C$. herbarum have minutely verruculose to echinulate or spiny conidia (Schubert et al. 2007). Conidia of similar species - C. oxysporum - are generally smooth. It is known that species of Cladosporium may inhabit substomatal chambers. Shorter superficial sterilization times may lead to higher percentage of Cladosporium. C. oxysporum was noted in bark and xylem of Eucalyptus grandis (Bettucci et al. 1999). Cladosporium cladosporoides was noted as endophyte in branches of Fraxinus excelsior and Pinus sylvestris (Kowalski, Kehr 1996) and Juncus spp. (Cabral et al. 1993). C. herbarum was isolated as endophyte 
in many different plants. Suková (2004) noted this fungus on stems of J. trifidus in Czech Republik.

Penicillium expansum Link, Obs. Mycol. 1: 16, 1809.

Figs 1B1, 1B2

Anamorph of Eupenicillium F. Ludw.

At the beginning colonies white (Fig. 1B1), after becoming grey to olivaceousgrey on Ferency medium (Fig. 1B2). Conidia pale yellow, smooth walled ellipsoidal 3-4 $\times 2,4-3 \mu \mathrm{m}$.

COMMENTs. Common fungus on fruits, meat, paper, various rotting substrates and soil (Domsch et al. 1980), known as Sorbus endophyte (Samson, Frisvad 2004). Also Batista et al. (2003) and Vega \& Posada (2006) informed that fungi from the genera Penicillium and Aspergillus where isolated as endophytes. P. expansum strongly suppressed growth of black yeast strain growing on nearest segment.

Basidiomycete endophyte, possibly Lagarobasidium detriticum (Bourdot \& Galzin) Jülich, Persoonia 10(3): 334, 1979. Syn.: Hypochnicium detriticum (Bourd. \& Galzin) J. Erikss. \& Ryvarden, Corticiaceae of North Europe (Oslo) 4: 701, 1976.

The white mycelium was growing on five segments of culm. Mycelium transferring on MAA medium has $54 \mathrm{~mm}$ diam. after five days and $80 \mathrm{~mm}$ after seven days. Mycelium white, velvety, pale yellow underside. At the beginning aerial mycelium cover all dish. Hyphae 3-5 $\mu \mathrm{m}$ diam., with clamps, spores smooth, ellipsoid 6-6.5 $\times 5-5.5 \mu \mathrm{m}$ diam. with a small apiculus and big oil drop. Crystals not seen. Cystidia not present, however similar structures were seen.

Comments. Size of spores resemble L. detriticum. Eriksson and Ryvarden (1976) noted L. detriticum on leaves of Juncus, Carex, Eqisetum, ferns, on rotten woods of Juniperus, Alnus, Betula, Populus and Sorbus. Basidiomycete endophytes are not often isolated from plants. Some species from the genus Peniophora were isolated from xylem and bark of Eucalyptus globulus and they probably initiated the decomposition process (Bettucci et al. 1999).

\section{DISCUSSION}

Totally 11 strains of different fungi were isolated. Of them a black yeast, basidiomycete fungus, DSE and non-sporulating colonies will be subject of the next article. In this article are presented first result of presence of endophytes in the highland rush stems. Four isolated species of fungi have worldwide general distribution and were earlier noted as endophytes of various plants. The precise determination of the most interesting basidiomycete strain need sequencing of ITS region (Nilson 2003). Also comparison of frequency of various ecological groups of endophytes needs further investigation. So far any endophytes were isolated from stems of highland rush.

Acknowledgements. I especially thank to anonymous reviewer for important comments. This work was supported by the Ministry of Science and Information Society Technologies, Poland (Project No. 2 P04F 06628 and N N304 328336). 


\section{REFERENCES}

Adamska I. 2005. Fungal species new in Poland on Carex and Juncus. Acta Mycol. 40: 19-24.

Andrews J. H., Berbee F. M., Nordheim E. F. 1983. Microbial antagonism to the imperfect stage of the apple scab pathogen, Venturia inaequalis. Phytopathology 73: 228-234.

Bacon C.W. 1990. Isolation, cultures, and maintenance of endophytic fungi of grasses. (In:) D. P. Labeda (ed.). Isolation of biotechnological organisms from nature. McGraw-Hill Publishing Co., New York: 259-282.

Bacon C. W., Hill N. S. 1996. Symptomless grass endophytes: products of coevolutionary symbioses and their role in the ecological adaptations of grasses. (In:) S. C. Redlin, L. M. Carris (eds). Endophytic fungi in grasses and woody plants. APS press, St. Paul, Minnesota: 155-178.

Batista L. R., Chalfoun S. M., Prado G., Schwan R. F., Wheals A. E. 2003. Toxigenic fungi associated with processed (green) coffee beans (Coffea arabica L.). Intl. J. Food Microbiol. 85: 293-300.

Bettucci L., Alonso R., Tiscornia S. 1999. Endophytic mycobiota of healthy twigs and the assemblage of species associated with twig lesions of Eucalyptus globulus and E. grandis in Uruguay. Mycol. Res. 103: 468-472.

Bocher T.W. 1972. Evolutionary problems in the Arctic flora. In: D.H. Valentine (ed.). Taxonomy, Phytogeography and Evolution. Academic Press, London-New York: 101-113.

Cabral D., Stone J. K., Carroll G. C. 1993. The internal mycobiota of Juncus spp.: microscopic and cultural observations of infection patterns. Mycol. Res. 97: 367-376.

Chlebicki A. 1990. Brunnipila calycioides (Rehm) Baral an alpine fungus new to Poland. Acta Mycol. 26 (2): 33-36.

Chlebicki A. 2002. Biogeographic relationships between fungi and selected glacial relict plants. The use of host-fungus data as an aid to plant geography on the basis of material from Europe, Greenland and northern Asia. Monogr. Bot. 90: 1-230.

Ciaciura M. 1988. Charakterystyka rozmieszczenia górskich gatunków naczyniowych na Śląsku. Rozprawy habilitacyjne Akademii Medycznej we Wrocławiu 12: 1-157.

Clay K. 1989. Clavicipitaceous endophytes of grasses: their potential as biocontrol agents. Mycol. Res. 92: $1-12$.

Domsch K.W., Gams W., Anderson T.H. 1980. Compendium of soil fungi. Academic Press.

Drábkova L., Kirschner J., Seberg O., Petersen G. Vlček Č. 2003. Phylogeny of the Juncaceae based on rbcL sequences, with spezial emphasis on Luzula DC. and Juncus L. Plant Syst. Evol. 240: 133-147.

Ellis M. B. 1971. Dematiaceous Hyphomycetes CMI, Kew.

Eriksson J., Ryvarden L. 1976. The Corticiaceae of North Europe. 4. Blindern, Oslo: 547-886.

Fisher P. J. 1996. Survival and spread of the endophyte Stagonospora pteridiicola in Pteridium aquilinum, other ferns and some flowering plants. New Phytol. 132: 119-122.

Girlanda M., Isocrono D., Bianco C., Luppi-Mosca A.M. 1997. Two foliose lichens as microfungal ecological niches. Mycologia 89: 531-536.

Kohlmeyer J. Volkmann-Kohlmeyer B. 2000. Fungi on Juncus roemerianus 14. Three new Coelomycetes, including Floricola, anam. - gen. nov. Botanica Marina 43: 385-392.

Kowalski T., Kehr R. D. 1996. Fungal endophytes of living branch bases in several European tree species. (In:) S. C. Redlin, L. M. Carris (eds). Endophytic fungi in grasses and woody plants. APS press, St. Paul, Minnesota: 67-86.

Kulczyński S. 1924. Das boreale und arktisch-alpine Element in der mittel-europischen Flora. Bull. Acad. Polon. Sci Lettres, Ser. B (1923): 127-214.

Larran S., Monaco C., Alippi H.E. 2001. Endophytic fungi in leaves of Lycopersicon esculentum Mill. World Journal of Microbiology \& Biotechnology 17: 181-184.

Larran S., Perello A., Simon M. R., Moreno V. 2002. Isolation and analysis of endophytic microorganisms in wheat (Triticum aestivum L.) leaves. World Journal of Microbiology \& Biotechnology 18: 683-686.

Marchand P. J., Roach D. A. 1980. Reproductive strategies of pioneering alpine species: Seed production, dispersal, and germination. Arctic and Alpine Research. 12 (2):137-146.

Menéndez A., Bertoni M.D., Cabral D. 1995. Comparative study of occurrence of fungal endophytes in Juncus species from Argentina. Nova Hedwigia 60: 583-588.

Menéndez A., Bertoni M. D., Cabral D. 1997. Fungal endophytes in Juncus imbricatus var. chamissonis: identyfication of colonization patterns. Rev. Iberoam. Micol. 14: 125-128. 
Nilsson R. H. 2003. Phylogeny of the Hypochnicium punctulatum complex as inferred from ITS sequence data. Mycologia 95: 54-60.

Petrini O., Hake U., Dreyfuss M. M. 1990. An analysis of fungal communities isolated from fruticose lichens. Mycologia 82: 444-451.

Powell C. L. 1975. Rushes and sedges are non-mycotrophic. Plant and Soil 45: 481-484.

Pugh G. J. F., Buckley N. G. 1971. Aureobasidium pullulans: an endophyte in sycamore and other trees. Tran. Br. Mycol. Soc. 57: 227-231.

Samson R. A., Frisvad J. C. 2004. Penicillium subgenus Penicillium: new taxonomic schemes, mycotoxins and other extrolites. Stud. Mycol. 49: 1-260.

Schena L., Finetti Sialer M., Gallitelli D. 2002. Molecular detection of strain L47, Aureobasidium pullulans, a biocontrol agent of postharvest diseases. Plant. Dis. 86: 54-60.

Scheuer Ch. 1988. Ascomyceten auf Cyperaceen und Juncaceen im Ostalpenraum. Biblioth. Mycol. 123: $1-274$.

Scheuer Ch. 1996. Neuere Funde von Arthrinium-Arten (Hyphomycetes, Fungi Imperfecti) aus Osterreich. Osterr. Z. Pilz.5: 1-21.

Scheuer Ch. 1999. Some important corrections to the Ascomycetes recorded on Cyperaceae and Juncaceae from the eastern Alps by Scheuer (1988). Mycotaxon 23: 33-44.

Scheuer Ch., Chlebicki A. 1997. Recent collections of miscellaneous microfungi from South Poland. Acta Mycol. 32 (2): 147-172.

Sieber T. N., Sieber-Canavesi F., Dorworth C. E. 1991. Endophytic fungi of read alder (Alnus rubra) leaves and twigs in British Columbia. Canad. J. Bot. 69: 407-411.

Skalińska M., Banach-Pogan E., Wcisło H. 1957. Further studies in chromosome numbers of Polish Angiosperms. Acta Soc. Bot. Pol. 26: 215-246.

Stone J. K., Bacon C. W., White J. F. 2000. An overview of endophytic microbes. Endophytism defined. (In:) C. W. Bacon, J. F. White (eds). Microbial endophytes. Marcel Dekker, New York, Basel: 3-29.

Suková M. 2004. Fungi on Juncus trifidus in the Czech Republic. I. Czech Mycol. 56: 63-84.

Suková M., Chlebicki A. 2004. Fungi on Juncus trifidus in the Czech Republic (II) with taxonomical notes to some species. Czech Mycol. 56: 203-221.

Vega F. E., Posada F. 2006. Penicillium species endophytic in coffee plants and ochratoxin A production. Mycologia 98 (1): 31-42.

Volkmann-Kohlmeyer B., Kohlmeyer J. 1994. A new Aniptodera from saltmarsh Juncus. Botanica Marina 37: 109-113.

White J.F. Jr. 1987. Widespread distribution of endophytes in the Poaceae. Plant Dis. 71: 340-342.

Yurlova N. A., de Hoog G. S., Gerrits van den Ende A. H. G. 1999. Taxonomy of Aureobasidium and allied genera. Studies in Mycology 43: 63-69.

Kilka endofitycznych grzybów wyizolowanych z pędów situ skuciny (Juncus trifidus) z polskiej części Tatr

\section{Streszczenie}

Do badań wybrano populację situ skuciny rosnącą w masywie Czerwonych Wierchów w polskiej części Tatr. Pobrano materiały 19 prób pędów, wszczepiono 114 fragmentów pędów. Uzyskano 11 szczepów, z czego 5 opisano w niniejszym artykule: Arthrinium, anamorfa Apiospora montagnei, Cladosporium herbarum, Pennicillium expansum, Aureobasidium pullulans i szczep należący do grzybów podstawkowych, prawdopodobnie Lagarobasidium detriticum. 


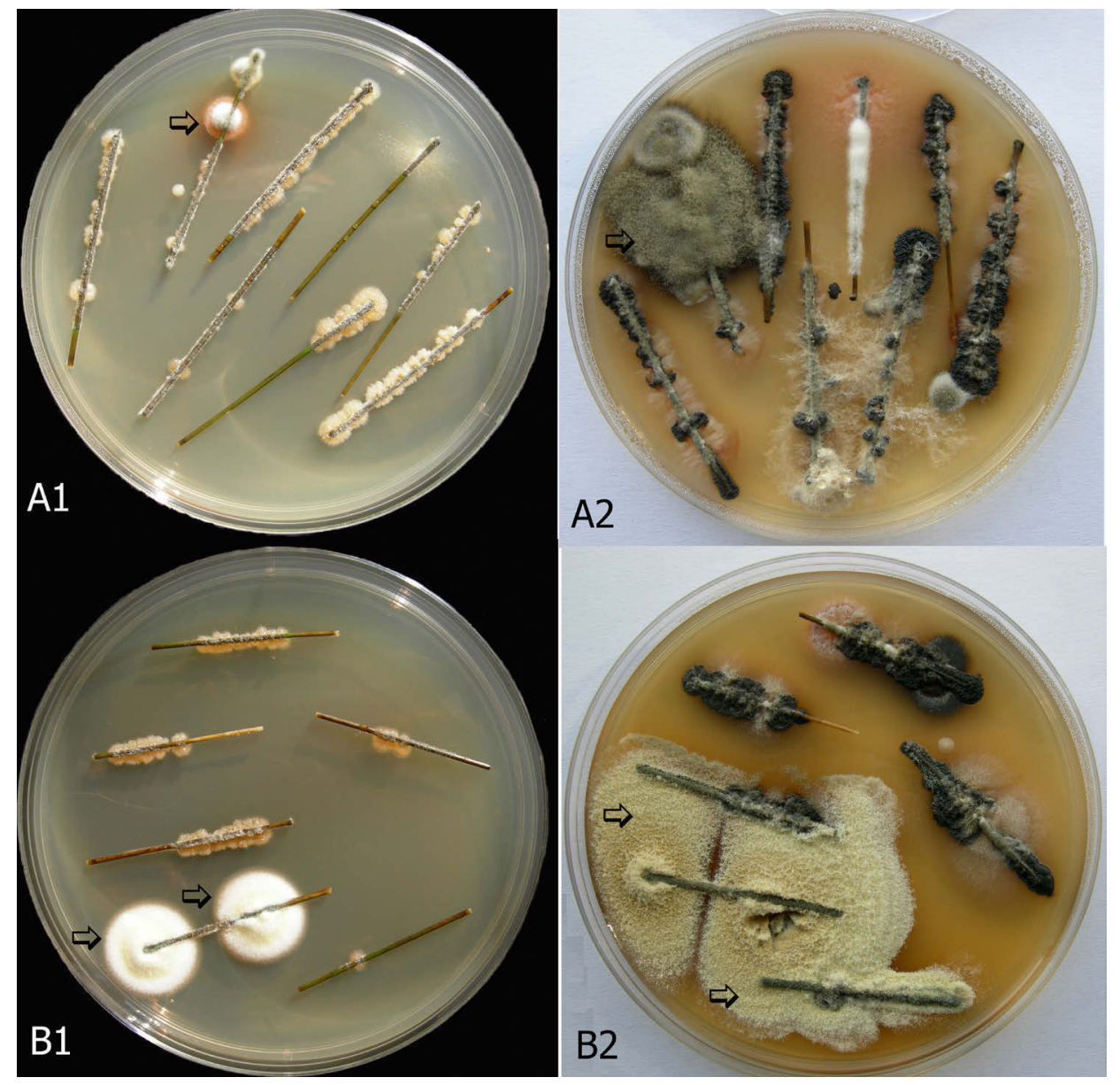

Fig. 1. Aureobasidium pullulans: A 1 - after 10 days; A 2 - after 30 days; Penicillium expansum: B1 - after 10 days; B2 - after 30 days. Both strains were cultivated on Ferency medium. 